\title{
Participação política na periferia leste de São Paulo: memória de antigos moradores (1940-1980)
}

\section{Political participation in periphery of São Paulo: memory of former residents (1940-1980)}

\author{
Adriana Santiago Rosa Dantas
}

Linguista pela Universidade de Campinas e mestra em Estudos Culturais pela Universidade de São Paulo

$$
\text { Graziela Serroni Perosa }
$$

Professora doutora da Escola de Artes, Ciências e Humanidades da Universidade de São Paulo

\section{Resumo}

Este artigo discute a participação política à luz de um distrito da Zona Leste de São Paulo, Ermelino Matarazzo, a partir do relato de antigos moradores que atuaram na região. Esta análise microssocial permitiu reconhecer a mudança de atores localizada no tempo e no espaço, relacionada a processos que acompanharam a formação da periferia paulistana como a industrialização, a migração, a autoconstrução, a favelização. Pretende-se demonstrar os diferentes atores e suas respectivas demandas que caracterizaram a participação tanto nas Sociedades de Amigos de Bairros (SABs) quanto nos movimentos por moradia entre as décadas de 1940 a1980.

Palavras-chave: participação política; periferia; Zona Leste; SAB, movimento por moradia.

\section{Abstract}

This article discusses the political participation of former residents who have worked of a district of East Zone of São Paulo, Ermelino Matarazzo. The microsocial approach allowed us to recognize the change of actors located in time and space, related to processes that accompanied the formation of the outskirts of São Paulo as industrialization, migration, and the development of slums. We intend to demonstrate the different actors and their demands on the participation of both the Societies of Friends of Neighborhoods (SABs) and in housing movements between the decades of 1940 to 1980.

Keywords: political participation; periphery; East Zone; SAB, housing movement. 
A periferia leste da cidade de São Paulo foi palco de muitas mobilizações populares ao longo da segunda metade do século XX. A participação política dos atores esteve imbricada ao processo de crescimento desordenado da cidade de São Paulo, o qual foi acompanhado de diversas carências de infraestrutura, catalizadores da mobilização popular. Muitos estudos têm contemplado as diversas associações ao longo do século XX, que se mobilizaram por um sistema público que atendesse saneamento básico, iluminação, educação e moradia (Andrade, 1989; Caldeira, 1984; Duarte, 2008; Duarte \& Fontes, 2004; Iffly, 2010; Gohn, 1991; Sposito, 2002; 2010).

Neste artigo, discutiremos esta participação política à luz de um distrito da Zona Leste de São Paulo, Ermelino Matarazzo, a partir do relato de antigos moradores que atuaram na região. Esta análise microssocial permitiu reconhecer a mudança de atores localizada no tempo e no espaço, relacionada a processos que acompanharam a formação da periferia paulistana como a industrialização, a migração, a autoconstrução, a favelização. Pretendemos demonstrar os diferentes atores e suas respectivas demandas que caracterizaram a participação tanto nas Sociedades de Amigos de Bairros (SABs) quanto nos movimentos por moradia entre as décadas de 1940-1980.

Este texto rediscute parte da dissertação de Dantas (2013). Naquela pesquisa, foram realizadas 18 entrevistas com antigos moradores de Ermelino Matarazzo que participaram da configuração do distrito após sua industrialização. Alguns excertos de entrevistados serão aqui utilizados como parte dos dados apresentados. Os nomes foram trocados. Para análise, utilizamos como referenciais teóricos textos das Ciências Sociais, da História Social, do Urbanismo e da Geografia, caracterizando a interdisciplinaridade metodológica na análise. O artigo está dividido em quatro partes: 1. "Os movimentos sociais na periferia leste do século XX", que visa dar um panorama das SABs e dos movimentos por moradia entre 1940 e 1980; 2. "O distrito de Ermelino Matarazzo" consiste em breve panorâmico histórico de como foi formada a região; 3. "A participação política em Ermelino Matarazzo" apresenta os diferentes atores situados no tempo e no espaço; 4. Encerra-se com as "considerações finais".

\section{Os movimentos sociais na periferia leste do século XX (1940-1980)}

A população do município de São Paulo em 1940 era de um pouco mais de 1 milhão de habitantes. Esta população dobrou de tamanho em 1950, chegando a 2.198.096. O crescimento se acelerava cada vez mais, constando que em 1960, São Paulo já tinha 3.781 .466 habitantes, sendo 49,41\% não naturais. Esta porcentagem já caracterizava o crescimento da capital paulista, que se deu primeiramente pela imigração no início do século XX e a migração interna já em seus meados. Em 1980, a população era de 8.443.226 contando com 50,90\% não naturais. Já na década seguinte, dos 9.646.185 habitantes de São Paulo, 38,28\% eram não naturais, porcentagem que se manteve também no ano 2000 (Histórico Demográfico do Município de São Paulo, 2013). O ritmo de migração começou a diminuir a partir dos anos de 1990, período em que a cidade teve seu saldo migratório negativo. (Perillo, 1996; Pasternak \& Bógus, 2005). Na atualidade, podemos verificar que a expansão populacional para o leste foi a mais significativa ao compararmos dados da Prefeitura de São Paulo em 2010:

Tabela 1: POPULAÇÃO POR ZONA EM SÃO PAULO

\begin{tabular}{|c|c|c|}
\hline Zona & População & \% \\
\hline Leste & 3998237 & 36 \\
\hline Sul & 3586020 & 21 \\
\hline Oeste & 2323745 & 8 \\
\hline Norte & 914395 & 3 \\
\hline Central & 431106 & 100 \\
\hline Total Município & 11253503 & \\
\hline Fonte: Infocidade (2013): População Recenseada em 2010. & & \\
\hline
\end{tabular}

Tal crescimento populacional trouxe consigo diversos problemas de infraestrutura na cidade, principalmente porque não esteve atrelado a políticas públicas de habitação. O direito à moradia nem sempre esteve 
presente na concepção dos novos moradores ou do poder público. Conforme Bonduki (1994), a questão habitacional não era atribuída ao Estado até 1930. Pela ideologia do início do século XX, o setor privado era o principal responsável por esta questão. Pelos dados acima, podemos perceber que o crescimento populacional trouxe também novas demandas sobre esta pauta na cidade. No período do pós-guerra de 1945-1964, a participação da população irrompeu de forma significativa no poder público com a ideia de que ele era o "novo" responsável pela questão habitacional. Neste período, a ação dos agentes populares surgiu com poder de barganha em cidades recém-industrializadas como São Paulo (Gohn, 2001, p. 90-91). Isto porque a cidade crescia pelo processo de periferização, o qual pode ser entendido como o incentivo de deslocar a classe trabalhadora, mesmo que não confessa como política de Estado, para os arredores da cidade (Mautner 1999; Rolnik, 2003; Grostein, 2004).

Os primeiros políticos a se beneficiarem destas novas conjunturas sociais eram os chamados populistas. Weffort (2003) assinala que a "mobilização social" da época populista foi caracterizada por um período em que vários setores sociais da população ficaram disponíveis para a política. Isto foi possível porque vários processos se imbricaram naquele momento, como a urbanização, as migrações, a expansão dos meios de comunicação em detrimento do meio rural em que grande parte da população era analfabeta, portanto, excluída da participação política.

A precariedade com que a cidade crescia permitiu que políticos como Adhemar de Barros e Jânio Quadros se valessem destes problemas como plataforma eleitoreira (Skidmore, 2010). O movimento de associações de bairros, atrelado à figura de Jânio Quadros, surgiu nos anos de 1930 como contraponto ao adhemarismo. Em São Paulo, Jânio Quadros aproveitou-se da estrutura das SABs, as quais estavam sendo organizadas em diversos bairros, inclusive cedendo terrenos para criação de novas sedes. Como "Jânio Quadros foi um dos primeiros a levar as questões sobre luz elétrica, transporte, moradia, escola, creche, saneamento básico, calçamento, etc. para dentro da Câmara Municipal" (Duarte \& Fontes, 2004, p.100), essa estratégia permitiu a mobilização da massa popular detentora de boa parte dos votos na cidade de São Paulo.

Naquele período, quem tinha capital para comprar grande parte dos terrenos na periferia os revendia, dividindo-os em lotes. No decorrer do tempo, com o aumento da infraestrutura destas regiões provenientes das lutas populares, o preço dos lotes aumentava consideravelmente, impossibilitando a compra para quem não tinha poder aquisitivo para tal. Nas palavras de Kowarick, "tratava-se de um 'laissez-faire urbano', produtor de enorme especulação imobiliária" (Kowarick, 2009, p.165). Como resultado, os antigos operários que compravam seus terrenos nos entornos das fábricas não tinham o mesmo poder de compra nos anos seguintes. $\mathrm{O}$ resultado consistiu na formação de favelas no final da década de 1970. Para Kowarick (2009), a formação das favelas se daria pelas décadas de 1980.

A participação política na periferia remete a uma luta da classe trabalhadora que se transmuta, na história da cidade de São Paulo, em uma luta pelo direito à cidade, no que se refere à moradia. Para Maricato, "trabalhadores do setor secundário e até mesmo da indústria fordista brasileira foram excluídos do mercado imobiliário privado e, frequentemente, buscaram a favela como forma de moradia" (Maricato, 2003, p.153). É o que a autora chama de "produtivo excluído". Mesmo ainda sendo uma força de trabalho utilizada na cidade, esses trabalhadores são excluídos da cidade legal. Conforme a autora, tais trabalhadores foram deixados de fora deste mercado imobiliário privado, mas permite-se que eles ocupem lugares ilegais na cidade, sem políticas públicas eficientes para habitação.

Alguns estudos apontam que a Zona Leste foi palco de uma singular luta por moradia na cidade de São Paulo (Andrade, 1989; Menezes, 2007; Iffly, 2010). O contexto político era a ditadura militar após o golpe de 1964. Este momento histórico proporcionou a reunião de diferentes modelos ideológicos: a Igreja (ideais cristãos), estudantes (a revolução), partidos políticos (revolução ou mesmo estruturação política), conforme Andrade (1989). Como já se tratava da favelização, os movimentos sociais se focalizavam no direito à habitação. Parte da Igreja que adotava este posicionamento tinha como doutrina a Teologia da Libertação no Brasil. Para Menezes (2007), seu argumento doutrinário era baseado na história do êxodo do povo judeu no Antigo Testamento, liberto da escravidão do Egito. Enquanto a mídia denominava “invasões", a Igreja da região denominava "ocupações" como referência direta ao êxodo bíblico em que o povo de Israel marchava para ocupar a terra prometida, evidenciando o caráter político-estratégico da ação (Iffly, 2010, p.171-186). As mobilizações 
se davam a partir da atuação das comunidades eclesiais de bases (CEBs). "As CEBs passam a representar a ação pastoral da Igreja, valorizando o papel do leigo - o homem do povo - na renovação da Igreja, proposta pelo Concílio Vaticano II" (Menezes, 2007, p.26).

\section{O distrito de Ermelino Matarazzo}

No início do século XX, Ermelino Matarazzo era um pequeno núcleo considerado rural com grandes descampados e densas vegetações à margem do rio Tietê. Era possível tomar banho no rio, pescar e ver animais nativos na região. Também era composta por chácaras de pequenos produtores rurais que abasteciam a cidade, dirigidas por imigrantes portugueses e japoneses. Havia também olarias cujas chaminés ainda fazem parte do cenário local (Caldeira, 1984, p. 33; Paiva, 2004, p. 54).

Naquela época, a região era de propriedade da família Matarazzo, um dos grandes industriais de origem italiana. A ferrovia Central do Brasil passava por aquelas terras, e em 1926 instalou-se uma variante denominada Comendador Ermelino, em homenagem ao filho do Conde Francisco Matarazzo, que morreu em um acidente de carro na Europa. Antes mesmo da instalação da estação de trem, a família Matarazzo já desejava expandir seus negócios, vendendo suas terras, segundo uma matéria da Folha da Manhã de 1925:

O "Jardim Matarazzo" ocupa uma área de 120 alqueires, 50 dos quais situados na várzea, junto ao Tietê, foram reservados para a edificação de grandes fábricas que as Indústrias Reunidas F. Matarazzo vão em breve instalar ali, a começar por um estabelecimento de cerâmica. Os 70 alqueires de colina é que foram divididos em lotes segundo uma planta bem calculada e já aprovada pela Prefeitura.

A prospecção da família Matarazzo se realizou. A divisão dos lotes da várzea para a indústria e as partes da colina para os loteamentos se concretizaram. As grandes glebas baratas permitiram a instalação de diferentes indústrias na região de várzea. Em 1941, a Celosul foi a primeira indústria de Ermelino Matarazzo, que, mais tarde, se tornou uma cooperativa denominada Copercell em 1991. Ela estava situada à margem da linha férrea, na variante Comendador Ermelino Matarazzo.

A região fazia parte de São Miguel Paulista e era apelidada de Ermelino Matarazzo devido à estação

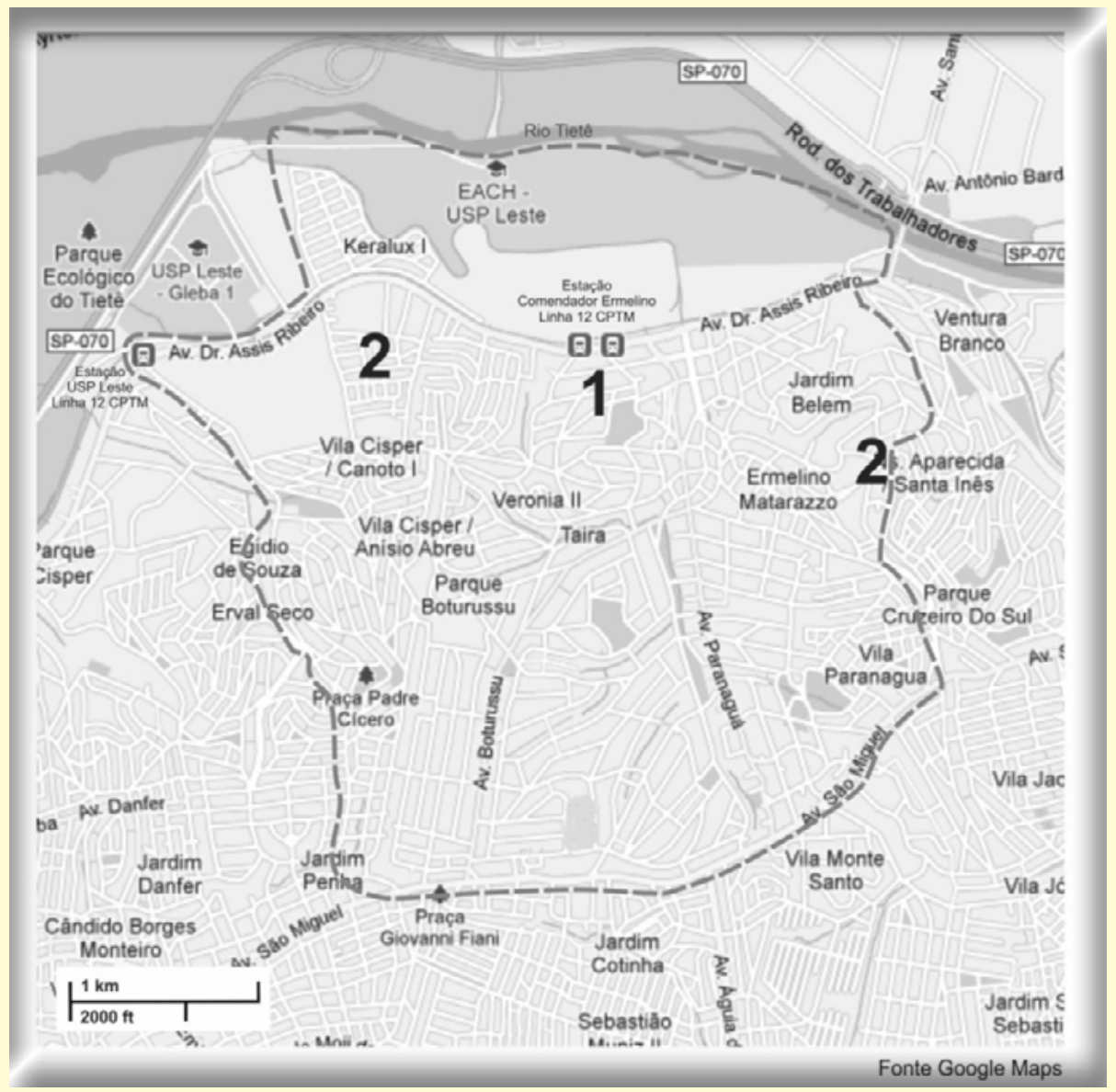

Mapa 1: Distrito de Ermelino Matarazzo do trem. Ela se tornou um bairro oficialmente em 1959 (Fontes, 2008, p. 127). Mais tarde, os limites dos distritos municipais foram definidos pela Lei no 11.220/1992, quando São Paulo passou pelo processo de "distritalização", que juntou bairros e vilas em 31 distritos; em 2013 mais um distrito foi desmembrado, somando-se 32 ao todo. Assim, as fronteiras atuais de Ermelino Matarazzo podem ser vistas no mapa ao lado:

O ponto 1 no mapa corresponde à estação de trem Comendador Ermelino Matarazzo e à antiga indústria Celosul. Uma das primeiras intervenções da Indústria Matarazzo foi construir uma vila operária, para funcionários de alto escalão. Para Kowarick (1993), a estratégia do empresariado era justamente trazer os operários para morar no entorno da indústria para reduzir os custos e, in- 
clusive, justificar um salário mais baixo. Assim, a construção da moradia era um bom investimento. Pouquíssimos funcionários tiveram acesso à vila operária, por isso, os trabalhadores compravam lotes e construíam a sua casa própria. Assim, também em Ermelino Matarazzo, "tornaram o trinômio loteamento popular/casa própria/autoconstrução a forma predominante de assentamento residencial da classe trabalhadora" (Mautner, 1999, p. 248). A partir de 1940, com a instalação da Celosul, o distrito recebeu grande população de operariado e profissionais liberais, como comerciantes, para atender estes novos moradores.

O fenômeno do loteamento/autoconstrução foi intenso até o final da década de 1970, quando os terrenos começaram a ficar muito caros para os trabalhadores locais. Naquele período, começou-se a formar as primeiras favelas (ponto 2 no mapa). As ocupações de terras aconteceram ao longo dos primeiros bairros e das indústrias, como a Vila Nossa Senhora Aparecida, o Jardim Keralux e o Pantanal, que tem como extensão a União de Vila Nova, já no distrito vizinho de São Miguel Paulista. Em outras palavras, ao redor da vila oficial (ponto 1 no mapa), formada pelo loteamento, estavam sendo formadas ocupações por moradores que não podiam mais comprar terrenos pelo alto preço da terra. Essa difícil situação também teria contribuído para a luta por parte dessas famílias para conseguir a efetivação de suas documentações sob a tutela da Igreja Católica que foi muito ativa ao abrigar esses movimentos populares em seu seio (Andrade, 1989; Iffly, 2010).

Estes dois momentos, representados pela "região dos loteamentos" (ponto 1) e a "região das ocupações" (ponto 2), tiveram contextos sociais e políticos diferentes. Por este motivo, foi possível verificar como a participação política dos atores foi se modificando ao longo do tempo e do espaço. As SABs e os movimentos por moradia tiveram diferentes atores que se explicam pelas conjunturas sociais, históricas e políticas pelas quais passavam a cidade de São Paulo entre 1940 e 1980.

\section{A participação política em Ermelino Matarazzo}

Depois da chegada da Celosul, Ermelino Matarazzo passou de uma região rural para urbana, no entanto, a infraestrutura básica era bastante precária. Como resultado, os novos moradores criavam associações sob o mote de busca de melhorias, especialmente no contexto político de cunho populista da década de 1950. Marcelo, um dos antigos moradores da região 1 dos loteamentos, assim relembra:

O bairro de Ermelino Matarazzo sempre foi muito ousado, muito forte em sociedade, sabe? Nós tínhamos no início uma Sociedade Amigos de Bairro muito forte onde muitos comerciantes antigos ajudavam, então tinha um grupo de pessoas que participavam e reivindicavam as coisas. Muitas pessoas aqui que já faleceram lutaram pelo bairro bravamente para conseguir asfalto, conseguir luz. Nós mesmos, a luz aqui, não tinha luz também na década de 70, nós fundamos uma sociedade amigos do Jardim Matarazzo que foi fundada aqui dos moradores.

Marcelo nasceu no interior de São Paulo, e seus pais eram italianos. Ele foi fazer faculdade em São Paulo, formando-se em Química. Chegou em Ermelino em 1962 para trabalhar em um cargo de chefia na Celosul. Como relata o entrevistado, Ermelino sempre foi muito forte em associações. Ele mesmo ajudou a fundar a SAB de Jardim Matarazzo. Outros bairros de Ermelino também tinham suas sociedades, como a principal a de Ermelino Matarazzo, assim como do Parque Boturussu e do Jardim Verônia. Nem sempre elas trabalhavam em conjunto, pois havia disputas de campo de atuação. $\mathrm{Na}$ verdade, o interesse de cada SAB era trazer melhoria local para o bairro que ela representava.

No caso de Ermelino Matarazzo, a liderança das SABs fazia parte de uma "elite" local que tomava a frente das reivindicações, dentre eles funcionários mais antigos e influentes do Matarazzo, como Marcelo, ou mesmo comerciantes, como Mateus. Este chegou criança a Ermelino Matarazzo, neto de italianos que foram trabalhar na colheita de café no interior de São Paulo. O pai de Mateus foi para a capital trabalhar na Nitro Química, importante indústria do distrito vizinho de São Miguel Paulista (Fontes, 1997). Mais tarde, aprendeu o ofício de alfaiate e foi trabalhar em Ermelino Matarazzo por causa da nova indústria, a Celosul, inaugurada em 1941. Levou a família para região em 1949. Quando Mateus cresceu, tornou-se sócio do pai alfaiate para instalar uma loja de roupas prontas, expandindo seu comércio. Mateus relembra de sua participação:

Aqui todas as entidades que tiveram aqui, en participei. Eu não sou politico, mas en gosto de fazer política. Então estou sempre envolvido com serviços sociais. (...) Geralmente, um grupo de comerciantes, a maior parte era grupo de comerciantes, a gente se reunia para reivindicar 
algumas coisas. Comerciante, profissional liberal, isso era o forte das associações que a gente tinha para reivindicar as coisas. Só que para reivindicar as coisas você tem que ter mais gente, gente influente para você ter força. Porque você vai sożinho pedir uma coisa para o governo ele nem te atende. Você vai lá com uma comissão representando o comércio, você marca uma audiência, você é recebido porque é interesse do politico receber você, entendeu? Porque é uma entidade que tem força. (...) Posto policial, segurança pública, escolas, transporte, a gente sempre reivindicou escolas, a gente continua reivindicando até hoje. No caso, na época do Carvalho Pinto, ele se dedicou muito à educação. Então era uma porta aberta para você ir reivindicar uma escola para o bairro que estava precisando. Então fazia uma associação, faz̧ia um abaixo-assinado; ia lá no planalto (sic) do governo. Ia lá reivindicar, às vezes não surgia em nada, não virava em nada, mas às vezes virava, entendeu? E a gente acabava conseguindo. Era iluminação pública, posto de saúde, entendeu?

Em sua reformulação do passado, Mateus justifica o porquê da hierarquização de profissionais liberais para representar os moradores diante do Estado. O poder de barganha popular estava calcado na influência que os representantes populares poderiam ter diante do poder público. Assim, as SABs eram "constituídas, em geral, por uma incipiente classe média do bairro - pequenos comerciantes, funcionários públicos, militares de baixo escalão, professores primários, um ou outro profissional liberal” (Sposito, 2002, p. 222).

Apesar desta hierarquização interna entre os habitantes de Ermelino Matarazzo, as reivindicações ao poder público eram tomadas em uma posição classista, isto é, era a classe trabalhadora se organizando em busca de direitos como moradores de uma localização carente de infraestrutura. Na verdade, como se constata em Ermelino Matarazzo, a mobilização neste período foi de grande importância para a consolidação do distrito. Houve, por exemplo, a aproximação das SABs de Ermelino com o governador Carvalho Pinto (1959-1963), como indica Mateus, para conseguir estabelecimentos escolares para a região. Naquele período, pós-janismo, foram instaladas três escolas estaduais no distrito de Ermelino Matarazzo, com destaque à escola Condessa Filomena Matarazzo, que oferecia o Curso Clássico/Científico, o equivalente ao Ensino Médio atual. Uma escola secundária na periferia na década de 1960 revela um vanguardismo na educação local (Sposito, 2010).

Para Duarte (2010), as SABs "eram parte de uma rede que compunha um fortíssimo e multifacetado movimento social no pós-guerra, que incluía também outras organizações de bairro, como clubes de futebol, dança, associações musicais" (Duarte, 2010, p.253). O autor questiona o não uso histórico da categoria "movimentos sociais" para as SABs, muitas vezes não definidas como tal na literatura sobre o tema. Em Ermelino Matarazzo, as SABs tiveram importante papel na instalação das escolas públicas desde 1956, inclusive no período da ditadura. De 1956 a 1964, foram instaladas quatro escolas públicas, incluindo uma de Segundo Grau (antigo Ensino Médio), e no período da ditadura, foram seis estabelecimentos (Dantas \& Perosa, 2012). Estes dados demonstram a complexidade da participação política destes moradores na esfera local. Além da educação, Carvalho Pinto foi associado ao tempo em que a água encanada chegou a Ermelino como relembra Marcelo:

Ai, na época do Carvalho Pinto que veio a água. [Antes da água encanada] Faz̨ia os poços, tinha a água, depois secava, afundava mais, depois desbarrancava. Era uma tristęa. Depois en pus bomba com luz elétrica, tirava água naquela manivela. Na Vila Matarazzo, eu tinha água, nós pegávamos água do Tietê e tinha um tratamento de água. Naquela ocasião, fazia tratamento dessa água, mas o Tietê era limpo praticamente né. Mas tinha que passar numa pedra de carvão, depois alguns produtos químicos, cloro, etc, porque servia para beber. A vila toda era abastecida pela água ali do Matarazzo.

Essas associações, como atestou Iffly (2010), eram organizadas em vista dessas dificuldades estruturais da região. No caso da água, era comum entre os moradores fazer poços artesianos para conseguir água em suas casas. Outra peculiaridade consistia no fato de a Vila Matarazzo ser abastecida pela água do rio Tietê, tratada a partir da Celosul. Mas este benefício chegava apenas nas localidades próximas à linha do trem, e o bairro já tinha se expandido, sendo necessária a intervenção pública no abastecimento de água.

Um fato muito peculiar da região dos loteamentos, decorrente das associações, consistia na organização de festas populares como a Festa de Primeiro de Maio e a Festa das Nações. Marcelo relatou o seguinte:

Essa sociedade conseguiu muitas coisas, pessoas que lutaram bravamente. Ela conseguia fazer uma Festa de Primeiro de Maio em Ermelino Matarazzo. Naquele tempo, eu também participava das comissões, que era espetacular. Era a maior festa de Primeiro de Maio que se tem notícia aqui em São Paulo. Faziam desfiles com escolas, ginásios que vinham do centro, colégios religiosos, vinham escoteiros, corpo de bombeiros. Tinha o corpo de bombeiros daqui e tinha o de lá, quase que fazia rivalidade com o da central porque a fábrica aqui era uma fábrica de alta periculosidade e a fábrica no 
meu setor eu trabalhava com setor de explosivos. Mas houve um desfile aqui com carros de bombeiros, os governadores. Ermelino sempre foi bem-servido de sociedade, e nessa sociedade se reivindicava.

A festa de Primeiro de Maio era o evento cultural mais importante de Ermelino Matarazzo. Também era uma vitrine para os políticos que participavam no apoio à festa, pois no evento tinha participação de honra nos pronunciamentos. Conforme o livro de memórias feito pela comunidade local, "o diferencial dos festejos de Primeiro de Maio de Ermelino Matarazzo em relação aos de outras localidades: [era] a entrega das reivindicações pela própria população" (Augusti, 2012, p.109). Era, portanto, uma festa política. Havia uma grande mobilização por parte dos organizadores como a Eliane. Ela veio do interior de São Paulo adolescente, após a morte de seu pai, e se empregou na Celosul trabalhando na cooperativa de alimentos da antiga fábrica. Foi morar em Ermelino em 1949, com a mãe e as irmãs. Casou-se com um funcionário da administração, tornando-se mais tarde dona de casa. Ela participava ativamente das SABs e era uma das organizadoras da festa, como relata:

No tempo do Maluf era do partido progressista, acho que tinha outro nome antes de ser progressista. Então a gente apelava para eles para ajudarem, sempre tinha quem ajudava, principalmente esse Primeiro de Maio. A gente ia para fazer esse Primeiro de Maio, a gente começava em outubro e ia em tudo quanto que é lugar e no palácio do governo. Eu fui muitas vezes, sempre tinha um governador. A gente ia lá pedir para fazer, para poder fazer o Primeiro de Maio, para ganhar as coisas, ganhava redes, bolas. Era no centro cultural que a gente ia para pedir as coisas, tudo.

Segundo Gohn (1991), as SABs foram desarticuladas no período militar, ressurgindo articuladas com a Igreja Católica. No interior de Ermelino, percebe-se que os dois momentos se fizeram distintos principalmente por causa dos atores envolvidos. Muitos dos comerciantes locais não participaram daquele momento posterior, assim como a luta por moradia na região trouxe novos protagonistas que não pertenciam ao grupo de comerciantes e moradores mais estabelecidos, que já tinham sua casa própria. À medida que se conseguiam os benefícios, as associações também foram diminuindo seu campo de atuação. Novas conjunturas no final da década de 1970, associadas à especulação imobiliária, às mudanças econômicas, políticas e trabalhistas delinearam um novo momento em Ermelino Matarazzo quanto à forma de moradia, que foi assim resumido por Marcelo:

Então, o que ocorre num lugar que está em ascensão, em progresso? As imobiliárias já pegam todos os lotes e depois põem o preço que elas querem e nem todo mundo pode pagar. Então, forçam a pessoa a ir para os barrancos, para os pantanais. Mas por que mora no Pantanal? A pessoa que fala assim não sabe quanto custa um terreno em Ermelino Matarazzo. E se eu tivesse chegado do interior e não tivesse condições de morar aqui, eu também teria ido morar no Pantanal.

A descrição de Marcelo resume de forma didática como acontecia a especulação imobiliária, cujas regras do jogo eram definidas por quem detém a propriedade de terrenos. Mesmo com dificuldades, os primeiros moradores, tanto da chefia, quanto operários da linha de produção, quanto comerciantes locais, conseguiram comprar seus terrenos no Jardim Matarazzo ou no Jardim Belém entre a década de 1940 e 1960 . Outros foram para o "Pantanal", uma das favelas que cresciam ao redor destes núcleos. Estas formações seriam as franjas das franjas. Em outras palavras, seria a periferia no interior de uma região que já é periférica, indicando uma das fronteiras da diferenciação interna do distrito, a partir do espaço ocupado. Em termos objetivos, algumas foram "urbanizadas" a partir de invasões, construções clandestinas, sem regularização, sofrendo constantes ameaças de serem expulsos a qualquer momento.

A partir dos relatos de algumas moradoras, foi possível compreender um pouco melhor a relação entre movimentos sociais, Igreja Católica e os migrantes que chegavam a partir de 1970. Em outras palavras, a participação política naquele período começava a se diferenciar da ocorrida na região dos loteamentos porque a demanda das reivindicações se modificava. É importante destacar que a migração de nordestinos se intensificava no local. Anteriormente, os moradores mais antigos de Ermelino Matarazzo, líderes das SABs, eram na sua maioria paulistas, descendentes de imigrantes europeus. Cada vez mais novos moradores, oriundos do Nordeste, chegavam à região em busca de novas oportunidades e acabavam se instalando irregularmente.

Uma das primeiras favelas de Ermelino Matarazzo tem nome de santa, a Santa Inês. Sua extensão, a favela Nossa Senhora Aparecida, também. A religiosidade da comunidade e a intervenção da Igreja Católica 
explicariam a predileção por assim nomeá-las. No final da década de 1970, conforme Andrade (1989), as lutas por moradia em Ermelino Matarazzo e São Miguel Paulista se intensificaram motivadas por moradores que compraram lotes de terrenos, mas não conseguiam receber a escritura definitiva, no entanto, a partir da diferenciação interna de Ermelino Matarazzo, é possível perceber que a situação de compra de lotes em uma região mais consolidada era diferente da de quem vivia no fio da clandestinidade, como os moradores de barracos e sua preocupação de perder tudo a qualquer momento, como aconteceu na região de ocupações. Anita veio do Piauí e chegou a São Paulo em 1977. Seu esposo era motorista e eles tinham três filhos. O preço do aluguel estava muito alto quando souberam da ocupação que acontecia na Santa Inês e decidiram encontrar um lugar para morar lá:

Eu cheguei aqui já morava muita gente, mas tudo em barraco de tábua. Não tinha nenhuma casa de material assim, que o pessoal tinha medo de fazer e a prefeitura vir derrubar. Como derrubaram umas ali, junto da escola. Naquele tempo que derrubaram eu já estava aqui. Fizeram tudo de material, ai o trator veio e derrubou tudo. Ai ficamos no barraco de tábua.

A antiga Favela Santa Inês, que agora é Comunidade Santa Inês, foi uma das primeiras regiões ocupadas em Ermelino Matarazzo. Menezes (2007) afirma que os movimentos populares de moradia sob a tutela da Igreja Católica ocuparam terrenos inativos da prefeitura: "Hoje, a antiga ocupação chamada de Favela Santa Inês é urbanizada e conta com a gestão paroquial de Pe. Ticão" (Menezes, 2007, p. 29). Assim, o protagonismo da Igreja Católica faz parte deste momento histórico das décadas de 1970 e 1980.

O Padre Ticão, cujo nome é Antonio Marchioni, nasceu em Urupês, interior de São Paulo. Estudou em São Carlos e foi parar em São Paulo para estudar Teologia porque queria se aproximar de Dom Evaristo Arns, um dos idealizadores das CEBs. Começou a atuar na Zona Leste no final dos anos de 1970. Em 1982, chegou à Paróquia São Francisco de Assis em Ermelino Matarazzo, onde completou 30 anos de ministério em 2012.

Em Ermelino Matarazzo é possível localizar geograficamente onde estiveram os focos das mobilizações. Há uma mudança de agentes e também de objetos para tais associações. Por um lado, as SABs buscavam melhorias para o bairro como iluminação, saneamento básico, escolas, por volta dos anos de 1950 e 1960. Já no período da ditadura, especialmente a partir dos anos de 1970, os movimentos formaram associações para buscar o direito à moradia, já impossível de ser adquirida pela própria valorização obtida nas décadas anteriores. Nas SABs, os agentes consistiam em profissionais liberais da região com poder de influência com o poder público. Quando um dos participantes, o Mateus, foi questionado se as reuniões das $\mathrm{SABs}$ aconteciam na igreja, ele respondeu o seguinte:

Olha, naquela época não! Porque as reivindicaçẽes com força da igreja mesmo foi depois que o padre Ticão veio. Porque tinha uma rotatividade de padres, um ficava dois anos, ai saía, vinha outro. Então o padre Ticão, quando veio, ele veio e ficou. E uma das maiores qualidades dele é brigar por serviços públicos, né, serviços para o bairro.

Antes da chegada do padre Ticão, as associações estavam por conta das SABs ou agremiações parecidas. Iffly (2010) propõe uma diferença entre esta época no populismo, para as ações mais estratégicas, principalmente por moradia, no período pós-ditadura. O Brasil já sinalizava a abertura política na época da chegada do padre Ticão, que teve uma forte participação nas lutas por moradia, chegando a ser preso por conta disto. Outra moradora do Jardim Matarazzo, a Eliane, muito ativa nas SABs também indica esta diferença de atores:

As lutas [por moradia], para falar a verdade, elas foram com o Ticão. Ele que comecou a ter essas lutas para as casas. Ai comecou. Eu não entrava nesse meio, não. Eu só comecei a entrar quando foi para a USP, porque na Vitória Simionato tem a Saem, que éa sociedade de amigos. A gente frequentava lá. A gente ia lá. Quando tinham essas coisas, a gente ia, mas não era sempre não, principalmente moradias, a gente não acompanhava, mulher geralmente não acompanhava.

Como a entrevistada relatou, ela frequentava a Sociedade de Amigos de Ermelino Matarazzo (Saem ). Segundo ela, mulheres não acompanhavam este tipo de luta por moradias, no entanto, segundo o próprio padre, a maioria que lutava nesses movimentos por moradias eram as mulheres, como a conhecida líder da região, a dona Neusa. Ela é falecida, mas é possível ver seu depoimento sobre as lutas por moradia no documentário Ermelino é Luz (2009). 
$\mathrm{Na}$ verdade, essa diferença está relacionada aos atores envolvidos. As mulheres da região dos loteamentos pouco participavam de reuniões sobre um lugar cuja clandestinidade e ilegalidades estavam em jogo por se tratar de uma "invasão", como aconteceu na região das ocupações. Mas nem por isso deixavam de participar de alguma reunião em busca de outras melhorias, como foi o caso da USP Leste, a Escola de Artes, Ciências e Humanidades (Each), cuja instalação teve forte participação popular da região (Perosa, Santos e Menna-Barreto, 2011).

É possível afirmar esta separação entre os antigos reivindicadores das SABs e os novos movimentos "adotados" pela Igreja Católica. Neste último caso, havia novas demandas de novos atores, que precisavam também exercer influência ante as autoridades. Tal negociação estava sendo realizada com e/ou pela a Igreja e não mais pelas lideranças das SABs. Uma das entrevistadas chamada Dora, saiu de uma região rural no interior da Bahia aos nove anos de idade para vir morar com parentes que já estavam em Ermelino Matarazzo. Chegou a São Paulo em 1970. Ao perguntar como foi o surgimento da comunidade Nossa Senhora Aparecida, ela explicou o seguinte:

Foi invasão. Naquela época, o padre (...) estava em frente dos trabalhos, estava à frente junto com nós. Então o terreno estava todo desocupado, era só mato. Então tinha seu Santo, tinha as outras meninas, como é que era? Eu nem lembro mais. Ai naquela época nós ajuntamos, o padre sabia que o terreno era da prefeitura, ai a gente ajuntou todo mundo, um grupo de pessoas, igual tem as invasões agora, invadimos e construímos um barraquinho, cada um construiu um barraquinho.

A “invasão” precisava ser orquestrada. Era necessária uma liderança local para reunir várias famílias, enfim, ter uma estratégia. Neste caso, uma liderança citada foi Seu Santo e, dentre "as meninas", ela citou mais tarde Dona Neusa, que esteve à frente da luta por moradia. Pelos relatos, pudemos ver o papel ativo das mulheres na liderança dos movimentos por moradia na região. As hierarquias no interior das mobilizações eram complexas, alvo de disputas como relata Anita sobre o seu Santo:

Ele ajudava as pessoas, trabalhava na comunidade, nas igrejas aí, pra ajudar as pessoas. Então as pessoas não tinham onde morar, eles arranjavam um cantinho pra morar. Ele foi uma pessoa muito boa que ajudou muita gente aqui. Ai terminou que assassinaram ele. A minha casa mesmo, uma parte nós compramos. Eu e minha prima, nós dividimos, ela numa parte e eu na outra. Ai como nós tinha mais filhos, ai quando o finado Santo tirou eles daqui e botou lá na outra rua de cima né. São Salvador, não sei como é que chama lá. Aí ficou um pedaço dela que caiu. Ai ele falou, esse pedaço não vamos dar pra ninguém, nós vamos dar pra essa familia que tem muito filho, muita gente que acaba que a casa épequena. Ai veio a assistente social concordou e deram pra nós.

Anita foi pessoalmente ajudada pela liderança de seu Santo, por isso ele era visto como uma pessoa boa aos seus olhos. O fato de ele ser assassinado demonstra que sua atuação não era bem quista por todos. Havia também nas mãos do seu Santo poder de decisão para indicar qual pessoa poderia morar ou não em algum lugar, sendo um elo entre a assistente social e os moradores. Para Iffly:

A população pobre empregou diversas estratégias nos anos 1980, algumas vezes consistindo em métodos aceitos pelas autoridades, outras ilegais. Muitas vezes, buscou fazer ouvir suas reivindicações, mas, quando o poder público não lhes deu ouvidos, também recorreu à ação direta. Enquanto o meio mais comumente empregado durante o período populista foi o abaixo-assinado, apresentado às autoridades por algum político, os movimentos pela moradia na década de 1980 inovaram de diversas formas. As ocupações de terras constituem uma forma de ação coletiva desconhecida no espaço urbano - talvez mesmo no repertório nacional (pode-se, a rigor, considera-las como importação de práticas já empregadas no campo, apesar de diferenças importantes). (Iffly, 2010, p.179)

Para a autora, esse tipo de ação orquestrada, legal ou não, assemelhava-se à ação do movimento dos sem terra empregada no campo. Por isso, a autora toma as ocupações de terras como uma ação coletiva inovadora. Ao mesmo tempo, a Teologia da Libertação, cuja doutrina entendia a terra como um direito, confrontava diretamente a especulação imobiliária, que tem ditado as regras na cidade. Por causa desse tipo de visão da Pastoral da Terra, da qual padre Ticão fazia parte, sobre a apropriação do solo urbano, uma investigação por parte da polícia federal foi iniciada contra o padre (Iffly, 2010, p. 178; Menezes, 2007). Dora relembrou:

Porque nós não tínhamos casa, não tínhamos onde morar, então a gente ajuntou um monte de gente, tinha uns moradores que já moravam aqui em barraco também. Fizemos uma turma e invadimos o terreno. Aí depois o padre entrou em contato com a prefeitura e conseguiu um papel que consta que a gente mora aqui, nós não temos posse. Mas ele lutou muito com nós, ele foi até preso por causa disso aí, dessa invasão. 
Um dos grandes temores dos moradores era o medo de perder seu investimento em construção de alvenaria por isso viviam em barracos de tábua. A intervenção da Igreja foi crucial para eles naquela época. Conforme já dito anteriormente, o objetivo da Igreja na Zona Leste, não era apenas defender os moradores de favelas dos problemas imanentes, como o despejo, demolição dos barracos, mas levar tais moradores a "reconhecer os seus direitos enquanto indivíduos" (Andrade, 1989, p. 62). As entrevistadas da região das ocupações confirmaram a importância da atuação da Igreja para a regularização das favelas. Conforme o depoimento de Anita:

Essas urbanizacões foram feitas depois que ele veio pra igreja aqui, é que foi feito esse calcamento. Chegou lu₹: Não tinha água, não tinha esgoto. Pegava água de poço. A luz era emprestada, quando dava seis horas, desligava as lâmpadas. Não dava nem pra iluminar dentro de casa. A gente ligava e queimava os nossos aparelhos tudo. Depois que ele começou a lutar pela gente aqui, entrou luz, a Eletropaulo. Aí foi começar a fazer a urbanização, veio esgoto, chegou água da Sabesp, a gente teve água em casa. Mas antes, a gente pegava tudo água do poço.

\section{Considerações finais}

Como procuramos mostrar, os agentes de Ermelino Matarazzo tiveram papel importante no que diz respeito à participação política entre as décadas de 1940 e 1980, no entanto, os movimentos sociais aconteceram por agentes e demandas distintas, localizadas em regiões que tinham diferentes características. As SABs surgiram em Ermelino Matarazzo após a instalação da indústria Celosul em 1941, marco do crescimento da região. Essas associações lutaram por melhoria de infraestrutura como luz, saneamento básico, escolas. Elas foram lideradas por moradores que já tinham sua casa própria, os quais eram majoritariamente profissionais liberais, que buscavam a consolidação da urbanização no poder público, a qual acontecia sem uma intervenção significativa dos governos municipais e estaduais. A partir da década de 1970, as ocupações de terra já se tornavam uma realidade no distrito. Estes novos atores consistiam, em sua maioria, em migrantes internos que chegavam a São Paulo em busca de novas oportunidades de emprego. Estes moradores, que ocuparam terrenos nos arredores dos bairros mais consolidados, tiveram que lutar não só por infraestrutura, mas principalmente pelo direito à moradia. Naquele contexto, atores das SABs recuaram, pois a natureza das reivindicações já ultrapassavam seus interesses. A participação da Igreja Católica se tornava, então, mais intensa. Sua importância se deu como mediadora diante do poder público, como também um lócus de formação política para a população de Ermelino Matarazzo sobre o direito à moradia.

\section{Referências bibliográficas}

ANDRADE, C. L. 1989 As lutas sociais por moradia de São Paulo: a experiência de São Miguel Paulista e Ermelino Matarazzo. São Paulo, SP. Dissertação de Mestrado. Pontifícia Universidade Católica de São Paulo.

AUGUSTI, W.A.(ed.). 2012. Memórias de Ermelino Matarazzo: um bairro paulistano, seu povo, sua gente. São Paulo: Ed. Do Autor,

BONDUKI, N.G. 1994. Origens da Habitação Social no Brasil. Análise Social, v. XXIX (127), (3º), 711-732.

CALDEIRA, T. 1984. A política dos outros: o cotidiano dos moradores da periferia e o que pensam do poder e dos poderosos. São Paulo: Brasiliense.

DANTAS, A.S.R.D. 2013. Por dentro da quebrada: a heterogeneidade social de Ermelino Matarazzo e da periferia. São Paulo, SP. Dissertação de Mestrado. Universidade de São Paulo.

\& PEROSA, G.S. 2012. Expansão escolar na periferia de São Paulo: o caso de Ermelino Matarazzo. Confluências Culturais, (online) Joinville/SC, n. 1, v.1.

DUARTE, A.L. 2008. "Em busca de um lugar no mundo": movimentos sociais e política na cidade de São Paulo nas décadas de 1940 e 50. Estudos Históricos. Rio de Janeiro, julho-dezembro, v. 21, n. 42.

2010. Algumas Considerações Sobre O Uso Da Categoria Movimentos Sociais. Cadernos Arquivo Edgard Leuenroth (Unicamp) v.17, n.29. 
\& FONTES, P. 2004. O populismo visto da periferia: adhemarismo e janismo nos bairros da Mooca e São Miguel Paulista (1947-1953). Cadernos Arquivo Edgard Leuenroth (Unicamp), v.11, n. 20/21.

ERMELINO é luz. Direção Pedro Dantas. Produção Maristela Grossi. Roteiro em conjunto com os alunos da vídeo-oficina Laboratório Documental de Construção da Poética Cotidiana. Mixagem e Masterização de Som: Denis Soria. Finalização: Ricardo Matias. São Paulo: PUC-SP, TV PUC São Paulo, Prefeitura da Cidade de São Paulo, 2009, 1 DVD (36 min), português, colorido, NTSC, Stereo 2.0. Coleção: II Edital História dos Bairros da prefeitura de São Paulo- Secretaria Municipal de Cultura.

FOLHA DA MANHÃ, 1925. Jardim Matarazzo. 6 de junho de, p. 7.

FONTES, P. 1997. Trabalhadores e cidadãos: Nitro Química: a fábrica e as lutas operárias nos anos 50. São Paulo: Annablume.

2008. Um nordeste em São Paulo: trabalhadores migrantes em São Miguel Paulista (1945-66) - Rio de Janeiro: Editora FGV.

GOHN, M.G. 1991. Movimentos Sociais e lutas pela moradia. São Paulo: Edições Loyola.

2001. História dos Movimentos e Lutas Sociais: a construção da cidadania dos brasileiros. $4^{\text {a }}$. Ed. São Paulo: Edições Loyola.

GROSTEIN, M.D. 2004. Periferias: loteamentos ilegais e formas de crescimento urbano. In: C.M. CAMPOS, L.H. GAMA, V. SACCHETTA (org.) São Paulo, metrópole em trânsito: percursos urbanos e culturais /- São Paulo: Editora SENAC.

HISTÓRICO DEMOGRÁFICO DO MUNICÍPIO DE SÃO PAULO. Disponível em <http://smdu.prefeitura.sp.gov.br/historico_demografico/index.php> Acessado em 26 de agosto de 2013.

IFFLY, C. 2010. Transformar a metrópole: Igreja Católica, territórios e mobilizações sociais em São Paulo 1970-2000. São Paulo: Editora UNESP.

KOWARICK, L. 1993. . A espoliação urbana. 2a . Ed. Rio de Janeiro: Paz e Terra. 2009. Viver em risco: sobre a vulnerabilidade socioeconômica e civil. São Paulo: Editora 34.

MARICATO, E. 2003. Metrópole, legislação e desigualdade. Estudos Avançados. 17 (48).

MAUTNER, Yvonne. 1999. A periferia como fronteira de expansão do capital. In: O Processo de Urbanização no Brasil. C. DEÁK, S.R. SCHIFFER (orgs.). São Paulo: Editora da Universidade de São Paulo,

MENEZES, R.T. 2007. Memória em Papel: o Jornalismo Popular e a Memória Coletiva. São Paulo, SP. Dissertação de Mestrado. Pontifícia Universidade Católica de São Paulo.

O ESTADO DE SÃO PAULO, 18 de janeiro de 1972. Caderno Geral, p.36;

PAIVA, O.C. 2004. Caminhos Cruz̧ados: migração e construção do Brasil moderno (1930-1950). Bauru, SP: Edusc.

PASTERNAK, S. \& BÓGUS, L.M. 2005. Migração na Metrópole. São Paulo em Perspectiva, v. 19, n. 4, p. 21-47, out./ dez.

PERILLO, S.R. 1996. Novos Caminhos da Migração no Estado de São Paulo. São Paulo Em Perspectiva, 10(2).

PEROSA, G. S. \& SANTOS, G.A. \& MENNA-BARRETO, L. 2011. Desafios da democratização do Ensino Superior. A USP no lado leste da cidade. In: Memória e Diálogo: escutas da Zona Leste, visões sobre a história oral. / R. SANTHIAGO e V. B. MAGALHÃES (org). São Paulo: Letra e Voz: FAPESP.

ROLNIK, R. 2003. A cidade e a lei: legislação, política urbana e territórios na cidade de São Paulo. $3^{a}$. ed. São Paulo: Studio Nobel: Fapesp.

SKIDMORE, T.E. 2010. Brasil: de Getúlio a Castello (1930-64). São Paulo: Companhia das Letras,

SPOSITO, M.P. 2002. O povo vai à escola. A luta popular pela expansão do ensino público em São Paulo. $4^{\mathrm{a}}$ Ed. São

Paulo: Edições Loyola,

2010. A ilusão Fecunda: a luta por educação nos movimentos populares. São Paulo: Hucitec,

WEFFORT, F.C. 2003. O populismo na politica brasileira. 5ª ed. Rio de Janeiro: Paz e Terra. 


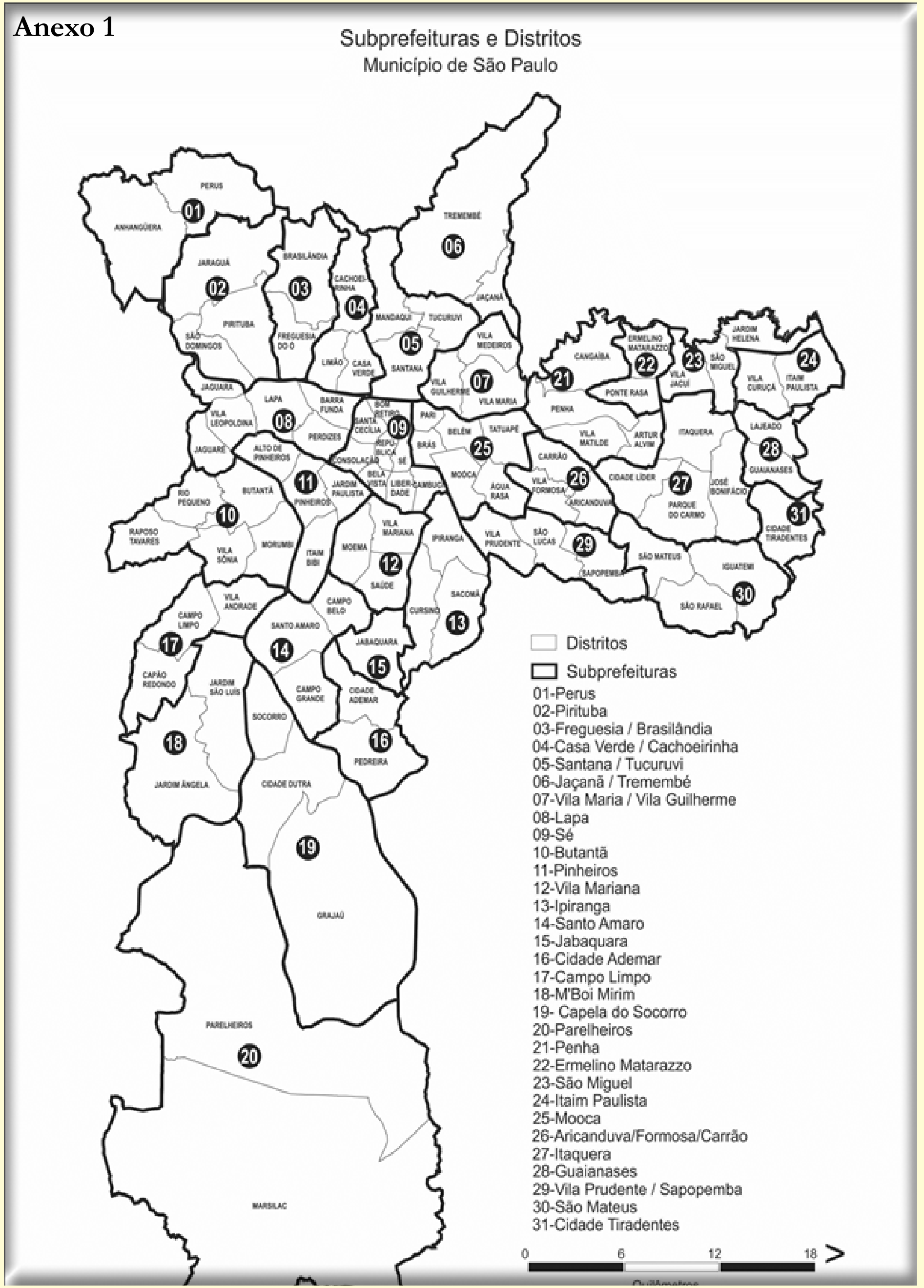

